\title{
ORGANIZATION OF THE ACCESS DATABASE OF THE VELES SMELTING FACILITY AREA, REPUBLIC OF NORTH MACEDONIA
}

\author{
Assoc. Prof. Dr. Goran Tasev ${ }^{1}$ \\ Doc. Dr. Dalibor Serafimovski ${ }^{2}$ \\ Doc. Dr. Todor Čekerovski ${ }^{2}$ \\ B. Sc. Gerasim Konzulov ${ }^{3}$ \\ Full Prof. Dr. Todor Serafimovski ${ }^{1}$ \\ ${ }^{1}$ Faculty of Natural and Technical Sciences, University “Goce Delčev"-Štip, R. N. Macedonia \\ ${ }^{2}$ Faculty of Electrical engineering, University "Goce Delčev"-Štip, R. N. Macedonia \\ ${ }^{3}$ Radoviš Municipality, Radoviš, R. N. Macedonia
}

\begin{abstract}
From the aspect of new and undiscovered conventional ore deposits of metallic raw materials the territory of Europe becomes more and more exhausted. In that regard slowly but steadily, alternatives are looked for. Namely, professionals became very aware of the anthropogenically introduced tailing and smelting dams/dumps and metal concentrations contained within. The European trends are leaning toward that path to provide fresh metal raw material sources for the developing industry. In that direction, bearing in mind long tradition of lead-zinc mining and smelting in Macedonia, especially $\mathrm{Pb}-\mathrm{Zn}$ mining in Eastern Macedonia and smelting of that ore in the Veles smelting plant we made an effort to organize the Access database of the anthropogenic concentrations of lead and zinc, as well as associated metals within the smelting slag. That represents pioneering attempt to synthesize data of this locality in one professional database available for the interested parties. The city of Veles occupies central part of the Republic of Norh Macedonia and lies on the both river banks of the Vardar river. Veles used to be the most polluted city in Macedonia due to the pollution from the former lead and zinc smelter plant located in the town. We would like to stress out that during its active period the factory processed 62,000 tones of zinc, 47,300 tones of lead and 120,000 tones of sulfur dioxide annually. This paper focuses on efforts we made to organize Microsoft Access database with the most representative data for this particular smelting location in the Republic of North Macedonia. At the very beginning, with the software package "Microsoft Access" we have organized database with information of the most important features of the former smelting plant locality. The database was adapted for simple and sophisticated querying of particular deposit features and allows edition of reports and a geographic display of the queried information. Major data that completed database for this area are: it is a former (inactive) smelting facility, there are significant anthropogenic concentrations and reserves of whole array of metals of which the most prominent are lead with average $0.8 \% \mathrm{~Pb}$ and potential of 14720 tonnes, zinc with average $4.2 \% \mathrm{Zn}$ and potential of 78630 tonnes, followed by indium with average $58.5 \mathrm{ppm} \mathrm{Li}$ and potential of 110 tonnes, lithium with average $16.0 \mathrm{ppm} \mathrm{Li}$ and potential of 30 tonnes and several other metals.
\end{abstract}

Keywords: Veles, smelting plant, Access database, anthropogenic concentration. 


\section{INTRODUCTION}

The former $\mathrm{Pb}-\mathrm{Zn}$ smelting plant took place in an immediate vicinity of the city of Veles, which is located in the valley of the river Vardar, about $55 \mathrm{~km}$ south from the capital Skopje. Veles, for many of its characteristics and features, is a specific urban and industrial area. In 2002, 55000 inhabitants were registered in the municipality of Veles, while the metropolitan area's population was 44000. This city used to be the most polluted city in Macedonia due to the pollution from the lead and zinc smelter plant located in the town. In 2003, when the factory was still in operation, the capacity of the smelter plant was 62000 tonnes of zinc, 47300 tonnes of lead and 120000 tonnes of sulfur dioxide annually (Nikolovski, 2008). The most concerning awareness was, as it was published by Kochubovski (2009), that smelting plant emissions lead to the increased concentrations of blood-lead levels in school children from Veles. Although mining and processing can present a substanal risk to environment, on the other hand mine waste materials and tailings represent valuable sources of secondary raw materials, including some of critical raw materials. The Republic of Norhern Macedonia is abundant in $\mathrm{Pb}-\mathrm{Zn}$ mines ( 3 of them) which have been exploited since Ancient times. The mining and especially smelting activities has generated mining, floatation and metalurgical tailings, which represent a potential for the European raw materials market sector. In this paper, as already mentioned above, we are dealing with the former $\mathrm{Pb}-\mathrm{Zn}$ smelting facility in Veles and its potential as anthropogenically introduced concentration of several useful metals and Access database compiled from data regarding that area.
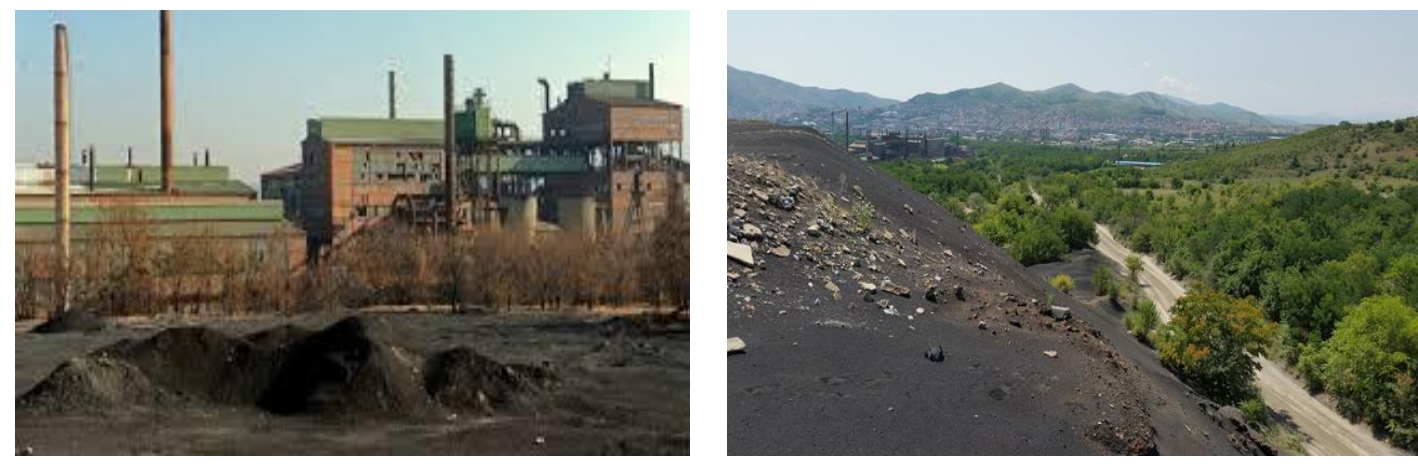

Fig. 1. Smelting plant Veles and smelting slag pile, city of Veles, Republic of Northern Macedonia.

The smelter site contains a large black pile of metalurgical tailings, whch consist of numerous industrially applicable metals $(\mathrm{Pb}, \mathrm{Zn}, \mathrm{Li}, \mathrm{In}, \mathrm{Ce}, \mathrm{Cd}, \mathrm{Cu}, \ldots . .$.$) . Some of the$ preliminary publications that have studied the issues of the Veles smelting facility area, its production and latter on pollution, can be found in [1], [2], [3], [4], [5], [6] and [7].

Up to date, in the Republic of Norhern Macedonia there weren't professional databases that should be in accordance to the European directives, although there is an initiative in ours Ministry of Economy that such database(s) should be prepared and included in similar modern European databases (ex. BRGM Mineral database). Here we were aiming to organize databases with an information about some of the most representative anthropogenic concentrations, smelting slag waste, such the former Veles smelting plant area is. Bearing in mind that the Veles smelting plant has a long history of processing, we knew that building aforementioned database is not an easy task to fulfill. Ours experience in organization of similar databases such are mine waste dumps (Bucim, Sasa etc.,) gave us the necessary knowledge and experience to construct quality Access 
database for this particular locality. We had to systematize data from operation longer than five decades. Organization of the Access database was carried out under several main topics, which are in accordance with the GIS related mineral databases principles given elsewhere [8], [9], [10], [11], [12] and [13].

\section{DISCUSSION}

In regards to the anthropogenic concentrations Access database we would like to display its several organizational entities:

General information address information about the location, status, latitude/longitude, ore district name, comments etc. (Figure 1).

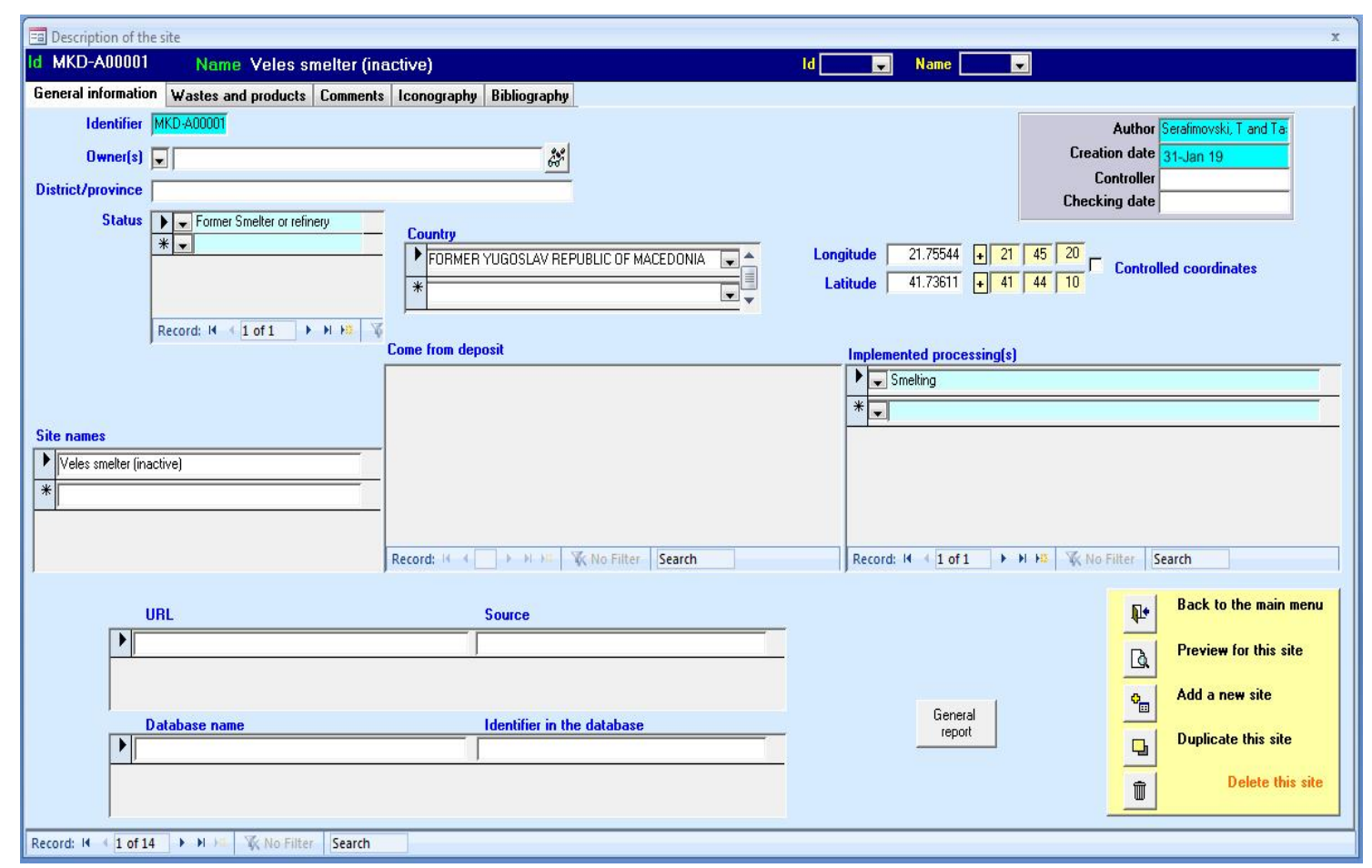

Fig. 1. General information datasheet of the anthropogenic database

For example on our sample of the Veles smelting plant slag dump we stressed out that is a an former facility with description of implemented processing methods, and prospective anthropogenic deposit with certain potentials in regards to lead, zinc and associated rare metals ( $\mathrm{In}, \mathrm{Li}, \mathrm{Cd}, \ldots)$. That information was followed by detailed coordinates and name of the company owner of the mine and production facility, as well as familiar names used by locals for the mine and short general comments.

Wastes and products sheet is organized in a manner that should be given details about the parameters: type of storage (surface, underground,...), type of waste (mine waste dump, slag,...), volume and surface occupied as well as tonnage and density of a particular waste-product, waste mineralogy, particular commodity and affected water area (Figure 2). Here potential of specific commodities in the anthropogenic products (e.g. $\mathrm{In}, \mathrm{Li}, \mathrm{Ce}, \mathrm{Pb}, \mathrm{Zn}, \mathrm{Cd}, \mathrm{Cu}, \ldots)$ related to certain host minerals was given, as well as grades (i.e. minimum, maximum and average grade) and abundance of host minerals in anthropogenic products. For ours particular locality, former smelting plant Veles, we have entered data about all different kinds of minerals such are galena, sphalerite, pyrite 
etc. There an accent was given to the significant quantities of lead with average $0.8 \% \mathrm{~Pb}$ and potential of 14720 tonnes, zinc with average $4.2 \% \mathrm{Zn}$ and potential of 78630 tonnes, followed by indium with average $58.5 \mathrm{ppm} \mathrm{Li}$ and potential of 110 tonnes, lithium with average $16.0 \mathrm{ppm} \mathrm{Li}$ and potential of 30 tonnes and several other metals.

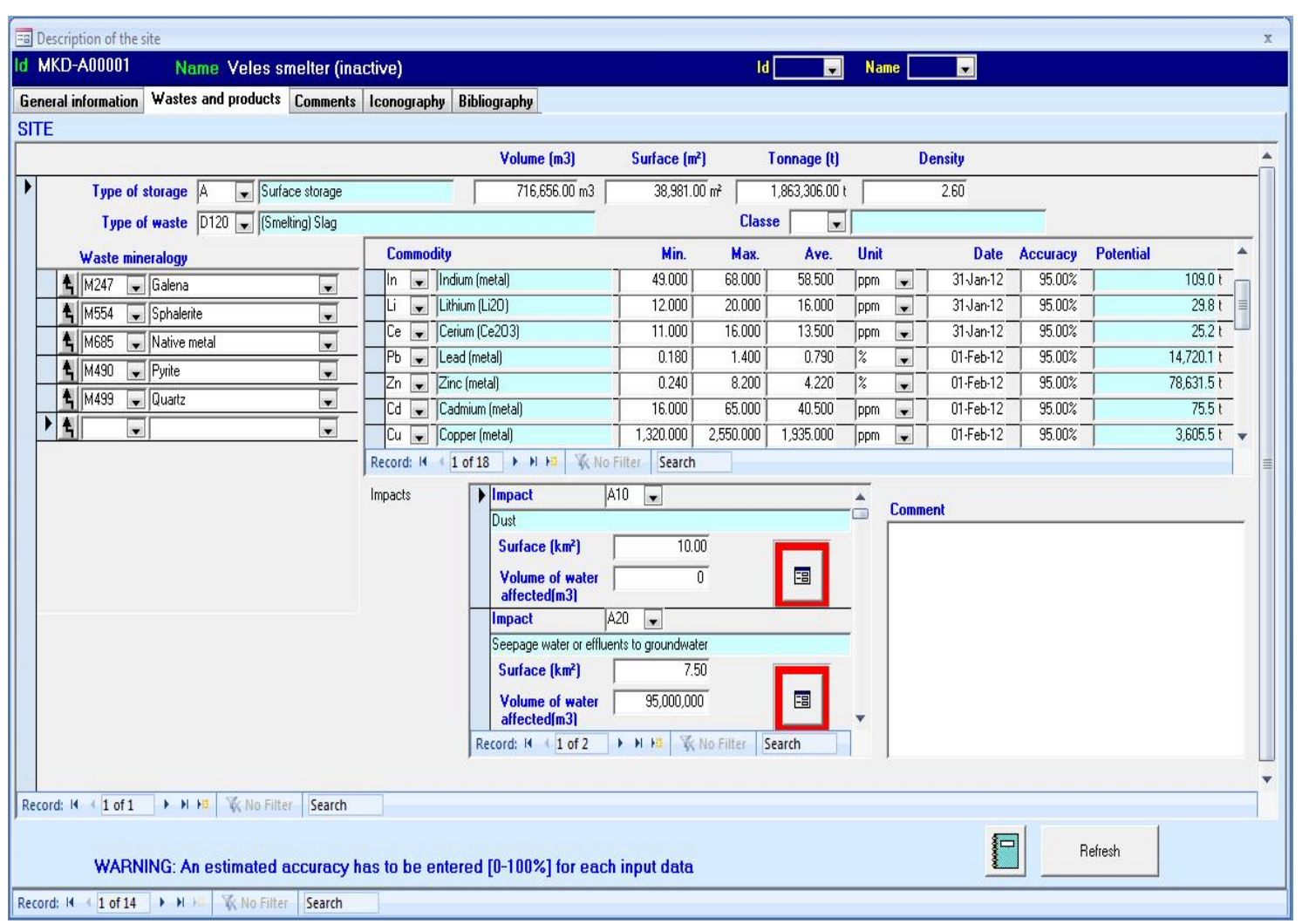

Fig. 2. Wastes and products datasheet of the anthropogenic database

Comments sheet, which is composed of space where it is possible to write free texts describing details about geology and/or details about economy of a particular anthropogenic concentration of potential metals gives a fine opportunity to describe particular concentrations in more details (Figure 3). For example for our location, anthropogenic concentrations, around the former Veles smelting plant, we have entered detailed, up to date findings, about the type, size, anthropogenic concentrations, details about the processing history of the locality as well as many other features such are past annual mine capacity, quantitative-qualitative parameters of produced ore, facility (facilities) where the raw excavated ore has been processed etc (Figure 3 ). 


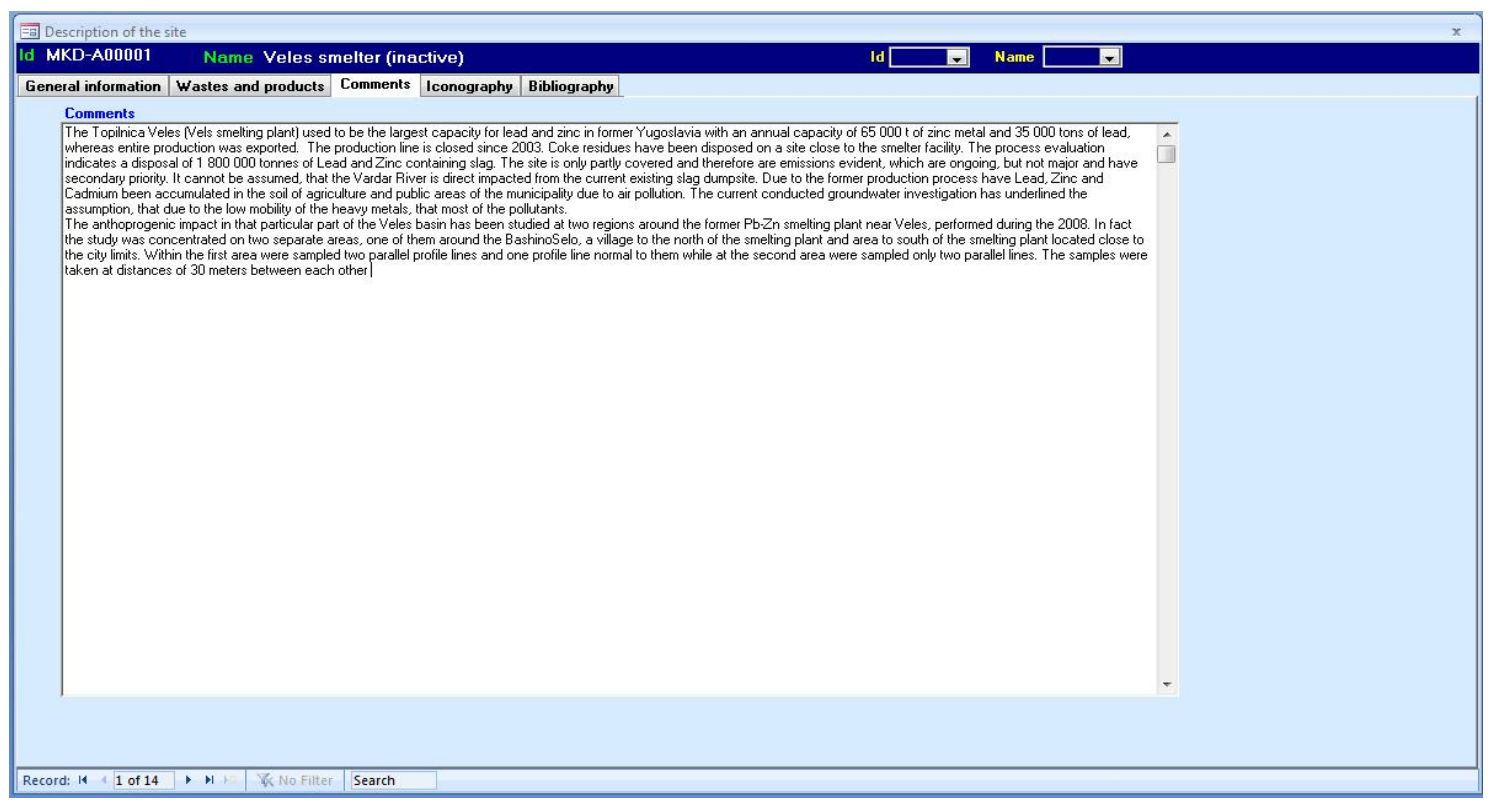

Fig. 3. Comments information datasheet of the anthropogenic database

Iconography sheet has been elaborated in order to attach images with an anthropogenic concentration. The first step being definition of paths of the image directory and the image viewer (e.g. Photo Editor, Windows picture viewer, Picasa...) by clicking on "Configuration" button quite similar to the mineral database above (Figure 4).

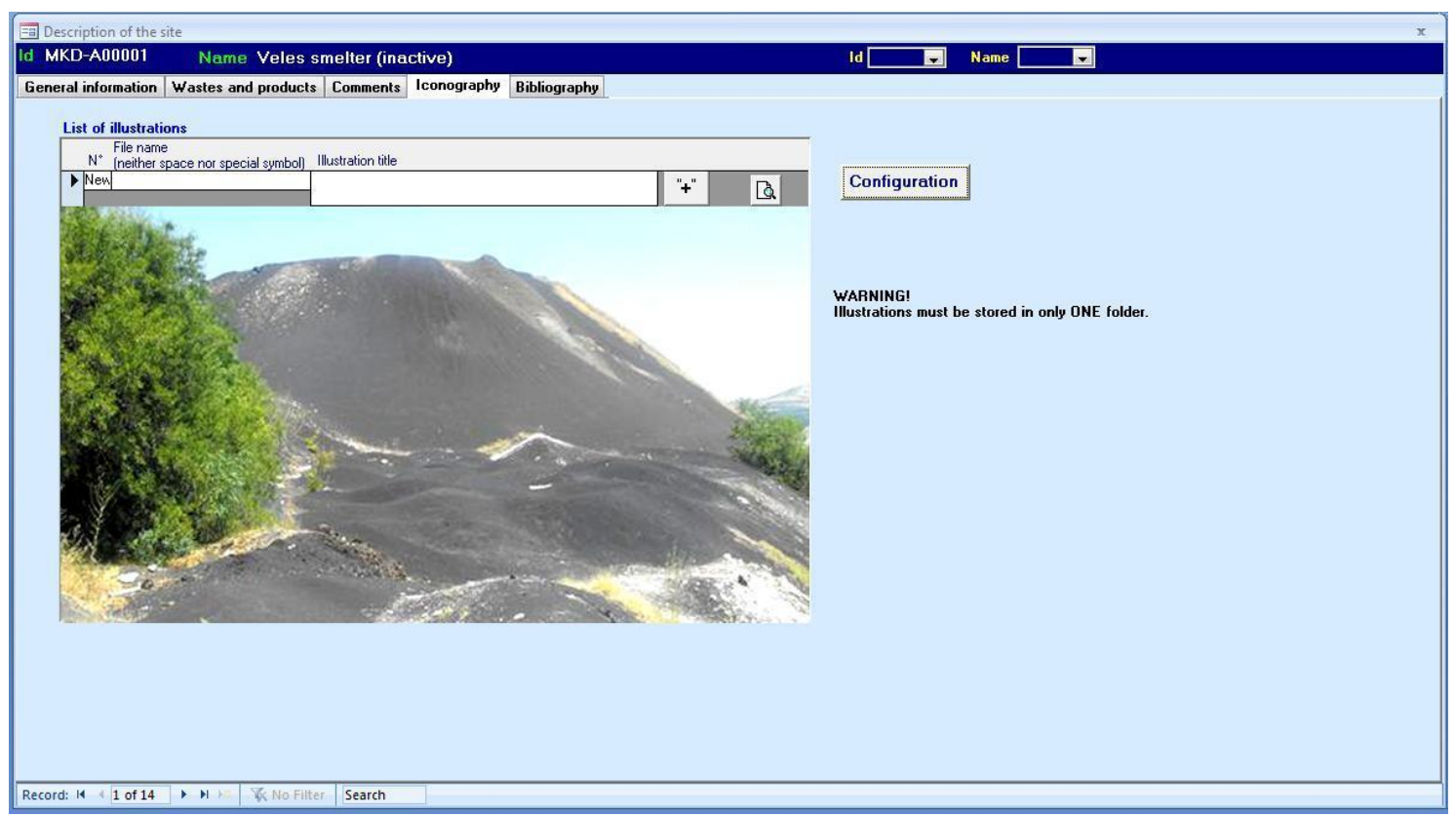

Fig. 4. Iconography information datasheet of the anthropogenic database

Bibliography data sheet for particular anthropogenic concentrations was intended to give an overview of available bibliography (references relating to the anthropogenic concentrations) and economical bibliography (references relating to economic data of the anthropogenic concentrations) and organizationally was quite similar to the previous database seen at Figure 5. 


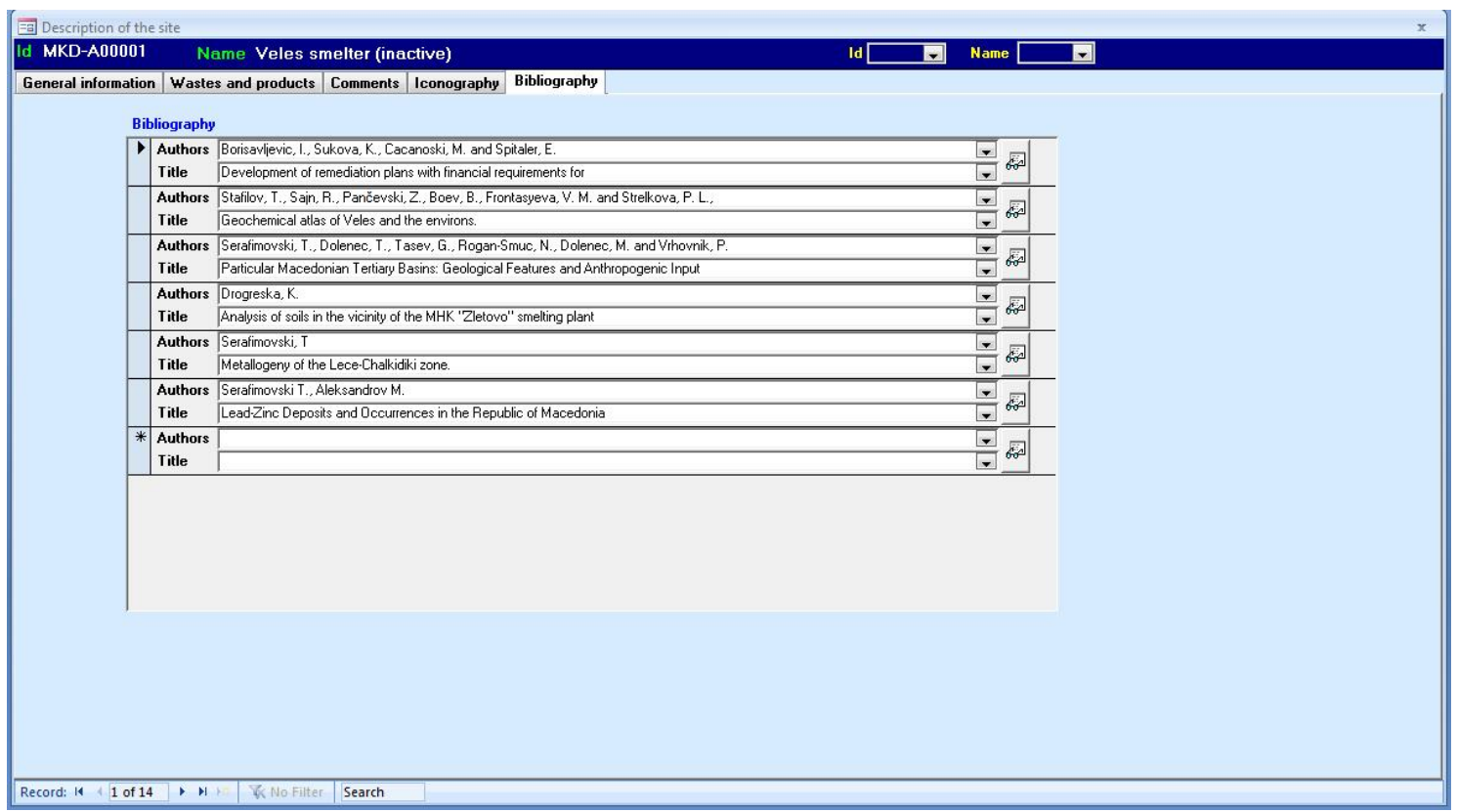

Fig. 5. Bibliography information datasheet of the database

For the Veles smelting plant area, we made significant input in regards to both types of bibliography, geological and economical ones. All the known and commonly used references to this particular deposit have been covered in this data sheet.

\section{CONCLUSION}

In the process of compiling the Access database for the Lojane Sb-As mine waste dump we kept in mind its anthropogenic reflections, had their major accents in the qualitativequantitative parameters and natural indicators in function to present and future valorization of metals that were subject to the establishment of the database, in accordance with professional mineral databases, as well as environmental and economic viability of the particular waste dump enclosed in form of an anthropogenic concentration Access database. The major findings and accents were that the Veles former smelting area contains certain lead-zinc potentials complemented by eventual by-products such are $\mathrm{Li}, \mathrm{Cu}, \mathrm{Ge}, \mathrm{Ag}, \mathrm{Cd}$, In etc. Certain parts of the database showed significant concentrations and quantities of lead with average $0.8 \% \mathrm{~Pb}$ and potential of 14720 tonnes, zinc with average $4.2 \% \mathrm{Zn}$ and potential of 78630 tonnes, followed by indium with average $58.5 \mathrm{ppm} \mathrm{Li}$ and potential of 110 tonnes, lithium with average 16.0 ppm Li and potential of 30 tonnes and several other metals. From the economic point of view those quantities able to generate an income of approximately 250000000 US (at actual metal prices) should not be ignored at all..

\section{REFERENCES}

[1] Nikolovski, Z. (2008). Polluted Macedonian city to be rid of smelter, SE European

Times,http://www.setimes.com/cocoon/setimes/xhtml/en_GB/features/setimes/fea tures/2008/05/01/feature-03.

[2] Kochubovski, M. (2009). Blood-lead levels in schoolchildren from Veles, related to the ambient air pollution by lead, exposure and risk assessment of 
chemical pollution-contemporary methodology, In: NATO Science for Peace and Security, Series C: Environmental Security, Springer, Heidelberg, pp. 371-378.

[3] Stafilov, T., Šajn, R., Pančevski, Z., Boev, B., Frontasyeva, M. V., Strelkova, L. P. (2008a). Geochemical Atlas of Veles and the Environs, Faculty of Natural Sciences and Mathematics, Skopje.

[4] Stafilov, T., Šajn, R., Pančevski, Z., Boev, B., Frontasyeva, M. V., Strelkova, L. P. (2010a). Heavy metal contamination of surface soils around a lead and zinc smelter in the Republic of Macedonia, Journal of Hazardous Materials, 175, 896914.

[5] Serafimovski, T., Dolenec, T., Tasev, G.,Rogan-Šmuc, N., Dolenec, M. and Vrhovnik, P., 2011. Particular Macedonian Tertiary basins: geological features and anthropogenic input. Proceedings of the $2^{\text {nd }}$ Workshop on the UNESCO-IGCP Project "Anthropogenic effects on the human environment in the Neogene basins in the SE Europe", Eds. T. Serafimovski \& B. Boev, Zagreb, Croatia, pp. 43-60.

[6] Serafimovski, T., Tasev, G. and Stefanova, V., 2014. Anthropoghenic soil contamination connected with active mines, smelting and plants in the Republic of Macedonia. Eurasian Journal of Soil Science, Vol. 3, Issue 4, pp. 293-302.

[7] Stafilov, T., Šajn, R. (2016). Geochemical atlas of the Republic of Macedonia, Faculty of Natural Sciences and Mathematics, Skopje.

[8] Albert, J.H., and Rossman, A.J., (2001). Workshop statistics: Discovery withdata, a Bayesian approach: Emeryville, Key College Publishing, 350 p.

[9] Cassard, D. and Itard, Y. (2003): Metallogenic and envi-ronmental information systems: A modern tool forthe sustainable development of mineral resources.In: Mineral resource base of the Southern Caucasus and sys-tems for its management in the XXI century, NATOScience Series, IV. Earth and Environmental Sciences, 17, 167-180.

[10] Goodchild, M. and Dopal, S., 1989. Accuracy of spatial databases. Taylor \& Francis, London.

[11] Harris, J.R., Wilkinson, L., Heather, K., Fumerton, S.,Bernier, M.A., Ayer, J. and Dahn, R. (2001): Application of GIS processing techniques for producingmineral prospectivity maps-a case study: mesother-mal $\mathrm{Au}$ in the Wayze Greenstone Belt, Ontario, Canada. Natural Resources Research, 10, 91-124

[12] Itard, Y., Geiller, M., Cassard, D. and Lips, A.L.W. (2002). Environmental dimension of a regional metallogenic synthesis: a way towards a sustainable extractive industry. GIS in Geology Int. Conference, Vernadsky SGM RAS, November 13-15, 2002, Moscow,Extended abstracts volume, 51-53.

[13] Vuollo, J., Cassard, D., Simons, B. and Seymon, A., (2010). The Earth resource data exchange model (EarthResourceML)-a tool for delivering ProMine and INSPIRE mineral resource data: INSPIRE Conference 2010 Presentation, Krakow, Poland, $37 \mathrm{p}$ 
